\title{
The Evaluation of Iranian EFL Learners' Interlanguage Pragmatic Knowledge through the Production of Speech Acts
}

\author{
Kim Hua $\operatorname{Tan}^{1} \&$ Atieh Farashaiyan ${ }^{1}$ \\ ${ }^{1}$ School of Language Studies and Linguistics, Universiti Kebangsaan Malaysi, Malaysia \\ Correspondence: Atieh Farashaiyan, A-17-6, Juta mines condo, Off Jalan Balakong, Jalan Taming Permai, \\ Serdang, Selangor, Malaysia. Tel: 60-17-305-8184. E-mail: atieh_farashaiyan@yahoo.com
}

Received: July 24, 2015 Accepted: September 18, 2015 Online Published: September 20, 2015

doi:10.5539/ass.v11n23p83

URL: http://dx.doi.org/10.5539/ass.v11n23p83

\begin{abstract}
This study evaluated Iranian intermediate EFL learners' knowledge of interlanguage pragmatic learning outcomes through the production of the speech acts of apology, request, and refusal. The study drew upon the conceptualization of Austin (1962) speech act theory and Brown and Levinson (1987) politeness theory as the theoretical framework of this study. The participants of the study included 235 EFL intermediate learners. Discourse Completion Task (DCT) was used as the instrument for data collection. The results of the data from the tests on speech acts showed that learners utilized more conventional or routinized strategies to perform these speech acts. Moreover, the results revealed that there were not so much differences in the frequency, shift and type of speech acts strategies or semantic formulas utilized in the production of speech acts by Iranian EFL learners in responding to a higher, an equal, and a lower-status person. The results also were suggestive of the learners' lack of pragmalinguistic and sociopragmatic knowledge. The implication of this study is for language teachers to teach interlanguage pragmatics explicitly in EFL contexts to draw learners' attention to both pragmalinguistic and sociopragmatic features, pay more attention to these areas and allocate more time and practice to solve learners' problems in these areas.
\end{abstract}

Keywords: EFL learners, interlanguage pragmatic knowledge, pragmalinguistics, sociopragmatics, speech acts

\section{Introduction}

In today's era of globalization and transculturalism, communication across cultural boundaries is an everyday phenomenon. Marlina (2013) states that the outreach of transnational corporations, the increment of human dynamics worldwide, the increased contact between people from different cultural backgrounds as a result of the progress of information technology have also contributed to the augmentation of encounters between individuals in the global system. As such, the exchanges of cultural values and practices, worldviews, and ideologies can emerge. Thus, it is vital to utilize language in socio-culturally appropriate ways which pragmatic competence plays a key role in this regard. Pragmatic competence is defined as "the ability to perform and produce language functions and speech acts in a context which is socially and culturally appropriate" (Taguchi, 2008, p. 34).

More recently, in EFL contexts, learners are required to utilize the English language for their communicative needs to do the business, read scientific articles, and use Information and Communication Technology (ICT) worldwide and so on. They also learn English and make use of it to interact with speakers of English from different cultures. As such, the English language plays a highly important role in intercultural interactions as a communication tool which calls into attention the issue of proper and appropriate intercultural understanding of speech or more importantly, meaning in interaction between speakers (Al-Zubeiry, 2013; Rashidi \& Ramezani, 2013).

However, cross-cultural misunderstanding occurs in the communication between individuals from different socio-cultural backgrounds and it is one of the difficulties that EFL speakers face in the act of communications (Rashidi \& Ramezani, 2013). It is claimed that the most important cause of intercultural misunderstanding is related to pragmatic failure in using the appropriate speech (Farahian, 2012). Hamouda (2014) believes that pragmatic failure emerges as unintentional offensive actions not deliberate mistakes due to the cultural diversity of individuals and their lack of knowledge in pragmatic rules and norms to realize speech acts in other cultures. For example, in Iranian culture, when somebody wants to make an offer or an invitation, the more direct and forceful the offer is, the more polite it is. But offers are made indirectly in English. Making an offer and refusing 
offers or invitation for the first time is what is named "Taarof" in Iranian culture. Thus, it obliges the host/hostess to insist more and ask the guest not to do "Taarof". In other cultures, there is no such ritual formality and they have different cultural norms. So, this case can cause intercultural misunderstanding between speakers.

Moreover, pragmatic failure is also rooted in the wrong use of communicative acts or speech acts as the social functions of language affecting the process of intercultural communication. Non-native speakers may just transfer speech acts from their first language to the target language to communicate the meaning. As such, pragmatic transfer, cultural variations, religious-oriented norms and social conventions can also contribute to pragmatic failures resulting in the communication breakdown across cultures (Al-Zubeiry, 2013). Therefore, in order to avoid intercultural misunderstandings and the resultant pragmatic failure, EFL learners' pragmatic knowledge as the core construct of communicative competence should be developed. This can result in more effective and successful intercultural communication (Nguyen, 2011; Rafieyan et al., 2014). In this regard, Eslami-Raseh (2011) also supports the previous statement and declares that learners' L2 pragmatic competence should be well developed in communicating appropriately in a target language.

The fact that Iranian EFL learners have continually faced with the challenges to communicate in L2 and they have mostly failed in their daily interactions have inspired SLA researchers to explore the status of EFL learners' L2 pragmatic competence in EFL classroom and examine learners' pragmatic knowledge development(Rajabi \& Farahian, 2013; Simin et al., 2014). Moreover, the research literature in pragmatic performance has shown that the studies done (Alfattah, 2009; Jebahi, 2013; Gu, 2014) were mostly intercultural in nature and compared the pragmatic performance of native speakers with non-native speakers with regard to the realization of speech acts strategies focusing on learners' pragmalinguistic knowledge. There is a paucity of study to investigate both learners' pragmalinguistic and sociopragmatic knowledge. As such, this study seeks to fill this void by evaluating Iranian EFL learners' interlanguage pragmatic knowledge (both pragmalinguistic and sociopragmatic knowledge) through the production of certain speech acts.

\section{Methodology}

\subsection{Participants}

Two hundred fifty two learners were chosen at the initial level of this study. After carrying out the OPT placement test, 235learners proved to be intermediate learners based on the test and the rest were not considered for the study. All of the learners were female since gender was not studied in this research as a variable and their age ranges between 18 to 45 years old. First, intermediate level learners were chosen as they are expected to have more or less a given consistency in the English grammar that they learned in the first semesters and also vocabulary knowledge sufficient at least to understand and perform basic communicative activities and also develop their pragmatic knowledge (Martinez-Flor \& Uso-Juan, 2010).

Second, the rationale behind choosing the intermediate level learners is that this level is considered as the optimal level for pragmatic learning (Kasper, 2006). In addition, learners shared basic demographic characteristics such as L1, cultural background and the same language proficiency to some extent. Third, Bardovi- Harlig and Dornyei (1998) and Hadley (1993) suggest that pragmatics is best taught and acquired when intermediate level L2 learners are involved. The last reason for choosing the intermediate level learners is that the textbooks' content of intermediate levels includes a variety of speech acts and speech acts strategies more than other levels.

\subsection{Instruments}

The test selected for the present study was a Written Discourse Completion Task or Test (WDCT), which is an internationally recognized and most common used test of measuring interlanguage pragmatic knowledge. The WDCT instrument was used for this study for several reasons. First, since the goal of this research was to measure learners' interlanguage pragmatic knowledge, the most efficient way to get the required data is through written discourse completion task (WDCT). Secondly, less time is needed to prepare and administer this kind of test for a large group of subjects. Thirdly, it allows participants more time to think about their answers and make use of different strategies compared to other tasks. More importantly, since the aim of the research was to measure both learners' pragmalinguistic knowledge in opting out the pragmatic forms and strategies and their sociopragmatic knowledge in considering the contextual factors of social power, distance and imposition, the WDCT was considered as the most suitable test for this reason. In this regard, Kasper (2000, p. 329) argues that a WDCT is an effective means of data collection when the purpose of the study is to "inform about speakers' pragmalinguistic knowledge of the strategies and linguistic forms by which communicative acts can be implemented, and about their sociopragmatic knowledge of the context factors under which particular strategic and linguistic choices are appropriate". In addition, Martinez-Flor (2006) declared that a WDCT is an 
appropriate instrument which reveals how respondents activate their interlanguage pragmatic knowledge.

Pragmatic production is the most important area of study in interlanguage pragmatics which is usually measured through a written questionnaire (Written discourse completion task). In this study, pragmatic production is operationalized as learners' oral performance in producing the speech acts of request, apology, and suggestion in reacting with a variety of situations. The request and apology tests were adapted from Liu (2005), and suggestion from Pishghadam \& Sharafadini (2011). All of the mentioned studies reported the validity of the used tests.

The rationale for the selection of these speech acts is that they are among the most used speech acts with frequent occurrences among other speech acts in the contents of the intermediate level textbooks. In addition, these speech acts are considered as both face-threatening and face-keeping acts as the central concepts of speech act and politeness theories and therefore they all call for redressive action. For example, requests affect the face of the hearer while apologies counteract the speaker's face wants (Blum-Kulka et al., 1989b).

Three situational variables (power, distance, and imposition/severity) were included in all of the speech acts. In terms of power relationships, the speaker may be in a lower or higher status than the hearer, and in some cases, they can also be equal in status. With regard to social distance, the speaker and hearer may know each other or in some cases, they do not know each other. Regarding imposition, the task can be of high imposition or low imposition. Since each speech act was adapted from the original test, the number of situations in each test is different. Moreover, each test includes a variety of situations with regard to three situational factors of power, distance and imposition to tap learners' both pragmalinguistic and sociopragmatic knowledge.

In this study, the request WDCT includes three situations which the test takers were required to write down their answers based on the situations involved. The situational variables of power, social distance and imposition were included in each item. The test included a variety of topics such as loud music, asking teacher to say something again, cell phone ringing in class. The apology WDCT consists of three situations containing three situational variables which the learners were required to read each situation and provide the answers as what they would say naturally. The test includes a variety of topics such as forgetting to do assignment, taking other's book by mistake and forgetting to teach French songs. Moreover, the required data for the speech act of suggestion were collected through a WDCT in which 6 natural situations were included, and learners were required to respond to the situations as naturally as possible. Furthermore, regarding the status, the situations involve lower, equal and higher-status relationship.

The validity of the three WDCTs was approved by the members of the dissertation committee and also three expert professors of School of Language Studies and Linguistics at University Kebangsaan Malaysia. They checked the content and face validity of all three pragmatic tests. With regard to the reliability of the WDCTs, the inter-rater reliability was conducted for all of three pragmatic tests. The inter-rater reliability estimates for WDCTs were satisfactory at around $0.92 \%, 0.94 \%$, and $0.89 \%$, for apology, request, and suggestion respectively which are acceptable indexes. For further evaluation of the reliability and validity, six learners were requested to participate in the semi-structured interview. After that, the tape-recorded interviews were transcribed by the interviewer. All of the participants stated that the tests are reliable and fair for tapping the pragmatic knowledge of Iranian EFL learners.

\subsection{Data Collection Procedure}

Before starting to accumulate the actual data for this study, a pilot study was conducted. In this regard, Ary et al. (2010) believed that conducting pilot study aids a researcher make a decision regarding the feasibility of the study and the appropriateness of research methodology and instruments. Therefore, they encourage a researcher to conduct a pilot study before the actual study. In the last two sessions of the academic semester of 2014, the pragmatics tests (WDCTs) were administered to intermediate EFL learners at five private language institutes. The number of intermediate EFL learners was 235 learners. This data collection was arranged at times suggested by the instructors in one session. The WDCTs including three speech acts of request, apology, and suggestion were distributed among the intermediate EFL learners in the class. They were given as much time as needed to provide the answers for the speech acts studied.

\subsection{Data Analysis}

The data accumulated through Written Discourse Completion Tests were analyzed and categorized according to different taxonomies in terms of the type and frequency of the semantic formulas or strategies used by learners. So, the taxonomy of Olshtain and Cohen (1983), Blum-Kulka et al. (1989), and Jiang (2005) were used for the speech acts of apology, request, and suggestion respectively. The justification for the use of afore-mentioned taxonomies is that they are validated by previous studies and they have been recognized as the most 
comprehensive and appropriate speech acts realization patterns. The presentation of each taxonomy is illustrated below.

Table 1. Apology taxonomy (Olshtain \& Cohen, 1983)

Strategy Example

\section{(1) Illocutionary Force Indicating Devices (IFIDs)}

a. An expression of regret, I'm sorry

b. An offer of apology, I apologize

c. A request for forgiveness, Excuse me/Forgive me/Pardon me

\section{(2)Explanation or Account}

Any external mitigating circumstances, 'Objective' reasons for the violation, The traffic was terrible

\section{(3)Taking on responsibility}

a. Explicit self-blame, It is my fault/my mistake

b. Lack of intent, I didn't mean it

c. Expression of self-deficiency, I was confused/I didn't see you/I forgot

d. Expression of Embarrassment, I feel awful about it

e. Self- dispraise, I'm such a dimwit!

f. Justify hearer, You're right to be angry

g. Refusal to acknowledge guilt

Denial of responsibility, It wasn't my fault

Blame the hearer, It's your own fault

Pretend to be offended, I'm the one to be offended

(4)Concern for the hearer, I hope I didn't upset you/Are you all right?

(5)Offer of Repair, I'll pay for damage

(6)Promise of Forbearance, It won't happen again

Table 2. Request taxonomy (Blum-Kulka et al., 1989)

\begin{tabular}{ll}
\hline Strategy & Example \\
\hline I. Direct Expressions & Please lend me a pen. \\
1. Imperatives & I'm asking you to lend me a pen. \\
$\begin{array}{l}\text { 2. Performatives } \\
\text { 3. Implicit performatives }\end{array}$ & I want to ask you to lend me a pen. \\
$\begin{array}{l}\text { 4. Obligation Statements } \\
\text { 5. Want Statements }\end{array}$ & You should lend me a pen. \\
$\begin{array}{l}\text { II. Indirect Expressions } \\
\text { II. A. Conventional indirect }\end{array}$ & I want you to lend me a pen. \\
$\begin{array}{l}\text { 6. Preparatory questions } \\
\text { 7. Suggestions }\end{array}$ & Could you lend me a pen? \\
8. Permissions & How about lending me a pen? \\
9. Mitigated Preparatory & May I borrow a pen? \\
$\begin{array}{l}\text { 10. Mitigated Wants } \\
\text { II. B. Non-conventional indirect }\end{array}$ & I'm wondering if you could lend me a pen. \\
11. Strong hint & I'd appreciate it if you could lend me a pen. \\
12. Mild hint & My pen just quit. I need a pen. \\
\hline
\end{tabular}


Table 3. Taxonomy for suggestion (Jiang, 2005)

\begin{tabular}{ll}
\hline Strategy & Example \\
\hline 1) Let's & Let's try... \\
& You have to... \\
2) Certain models and semi-models & You need to... \\
& You'd/had better \\
(3) Wh-questions & Why don't you....? \\
(4) Conditionals & If I were... \\
& I suggest... \\
(5) Performatives & I propose... \\
& My suggestion is... \\
(6) Pseudo cleft structures & My recommendation is... \\
(7) Extraposed to-clauses & All you need to do is... \\
(8) Yes/no questions & It might be difficult to... \\
(9) Imperatives & Have you heard... \\
\hline
\end{tabular}

\section{Results}

In order to answer the research question, the data were collected through the Written Discourse Completion Test/Tasks (WDCTs). The researcher examined learners' interlanguage pragmatic knowledge through the production of three speech acts of apology, request, and suggestion. It was aimed to evaluate learners' knowledge in production of accurate and appropriate speech act strategies or linguistic forms as well as situational understanding of three factors of social power, distance and imposition. In so doing, they were given some situations for each speech act and they had to write the answers to the situations based on what they would say verbally for each scenario.

The tables below represent the descriptive results gained based on frequency of the speech acts' strategies and the corresponding percentage in each situation. Needless to say, the items of the questionnaires differ in terms of social distance, power and rank of imposition to tap learners' awareness in using various strategies.

Table 4. Frequency and percentage of apology strategies across situations

\begin{tabular}{llllllllll}
\hline Apology Strategies & \multicolumn{1}{l}{ Situation 1 } & \multicolumn{1}{l}{ Situation 2 } & \multicolumn{2}{l}{ Situation 3 } & \multicolumn{2}{l}{ Total } \\
\hline 1)Illocutionary Force Indicating Device & $\mathbf{F}$ & $\mathbf{P}$ & $\mathbf{F}$ & $\mathbf{P}$ & $\mathbf{F}$ & $\mathbf{P}$ & $\mathbf{F}$ & $\mathbf{P}$ \\
& & & & & & & $\mathbf{7 9}$ & $\mathbf{3 6 . \%}$ \\
a. An expression of regret & 20 & $30.3 \%$ & 24 & $34.2 \%$ & 17 & $21.5 \%$ & 61 & $28.3 \%$ \\
b. An offer of apology & 0 & - & 4 & $5.7 \%$ & 3 & $3.7 \%$ & 7 & $3.2 \%$ \\
c. Request for forgiveness & 5 & $7.5 \%$ & 2 & $2.8 \%$ & 4 & $5 . \%$ & 11 & $5.1 \%$ \\
2)Explanation or Account & 9 & $13.6 \%$ & 9 & $12.8 \%$ & 13 & $16.4 \%$ & 31 & $14.4 \%$ \\
3)Taking on responsibility & - & - & - & - & - & - & - & $27.8 \%$ \\
a. Explicit self-blame & 0 & - & 0 & - & 0 & - & - & - \\
b. Lack of intent & 0 & - & 7 & $10 \%$ & 0 & - & 7 & $3.2 \%$ \\
c. Expression of self-deficiency & 14 & $21.2 \%$ & 7 & $10 \%$ & 18 & $22.7 \%$ & 39 & $18.1 \%$ \\
d. Expression of Embarrassment & 2 & $3.03 \%$ & 8 & $11.4 \%$ & 2 & $2.5 \%$ & 12 & $5.5 \%$ \\
e. Self-dispraise & 0 & - & 0 & - & 0 & - & 0 & 0 \\
f. Justify hearer & 0 & - & 2 & $2.8 \%$ & 0 & - & 2 & $0.9 \%$ \\
g. Refusal to acknowledge guilt & 0 & - & 0 & - & 0 & - & 0 & 0 \\
\hline
\end{tabular}




\begin{tabular}{lllllllll}
\hline Apology Strategies & Situation 1 & Situation 2 & Situation 3 & \multicolumn{2}{l}{ Total } \\
\hline - Denial of responsibility & 0 & - & 0 & - & 0 & - & 0 & 0 \\
- Blame the hearer & 0 & - & 0 & - & 0 & - & 0 & 0 \\
- Pretend to be offended & 0 & - & 0 & - & 0 & - & 0 & 0 \\
4)Concern for the hearer & 0 & - & 1 & $1.4 \%$ & 0 & - & 1 & $0.4 \%$ \\
5)Offer of Repair & 14 & $21.2 \%$ & 6 & $8.5 \%$ & 21 & $24.3 \%$ & 41 & $19 . \%$ \\
6)Promise of Forbearance & 2 & $3.03 \%$ & 0 & - & 1 & $1.26 \%$ & 3 & $1.3 \%$ \\
Total & 66 & $100 \%$ & 70 & $100 \%$ & 79 & $100 \%$ & 215 & $100 \%$ \\
\hline
\end{tabular}

$\mathrm{F}=$ Frequency, $\mathrm{P}=$ Percentage.

As shown in the above table, learners were given three different situations to make an apology. The results showed that in terms of illocutionary force indicating device, the respondents showed the highest overall ability which means that more than $28 \%$ of the respondents could use an expression of regret to apologize. Respondents had low ability in choosing a sentence after representing their regret by either an offer for an apology or a request for forgiveness which were $3.25 \%$ and $5.11 \%$ respectively. As a whole, IFIDs were the most frequently used strategy by learners (36.73\%) followed by Taking on Responsibility (27.89\%), Offer of Repair (19.06\%), Explanation (14.41\%), Promise of Forbearance (1.39\%) and Concern for the hearer $(0.46 \%)$ as the second, third, fourth, fifth and last strategies used by the learners. Therefore, IFIDs with $36.73 \%$ and concern for the hearer with $0.46 \%$ were the most frequentand least used apology strategies.

Among the taking on responsibility strategy, none of the respondents used an explicit sentence of self-blame, self-dispraise, deny the responsibility, blame the hearer and pretend to be offended. Only 2 respondents in situation 2- mistakenly taking a classmate's book- and 7 respondents in situation two showed their lack of intent. The respondents were not able to show their concern for the hearer as only 1 respondent out of 215 could perform this strategy. 41 respondents could offer for repair while only 3 respondents could promise forebearance. Overall, intermediate learners' knowledge in apologizing in different situations were far too low.

With regard to each situation, the most frequent used strategy was IFIDs in all of them. In situation one, the most frequent used strategy was IFIDs with $37.8 \%$ and the least used one was concern for the hearer. None of the respondents showed concern for the hearer. This trend was the same in situation three. In situation two, in contrast, the least used strategy was promise of forbearance. None of the respondents made use of this strategy. Therefore, the findings are suggestive of the fact that the learners almost utilized the same strategies across all the situations and they did not show any variations with regard to three contextual factors of social power, distance and imposition.

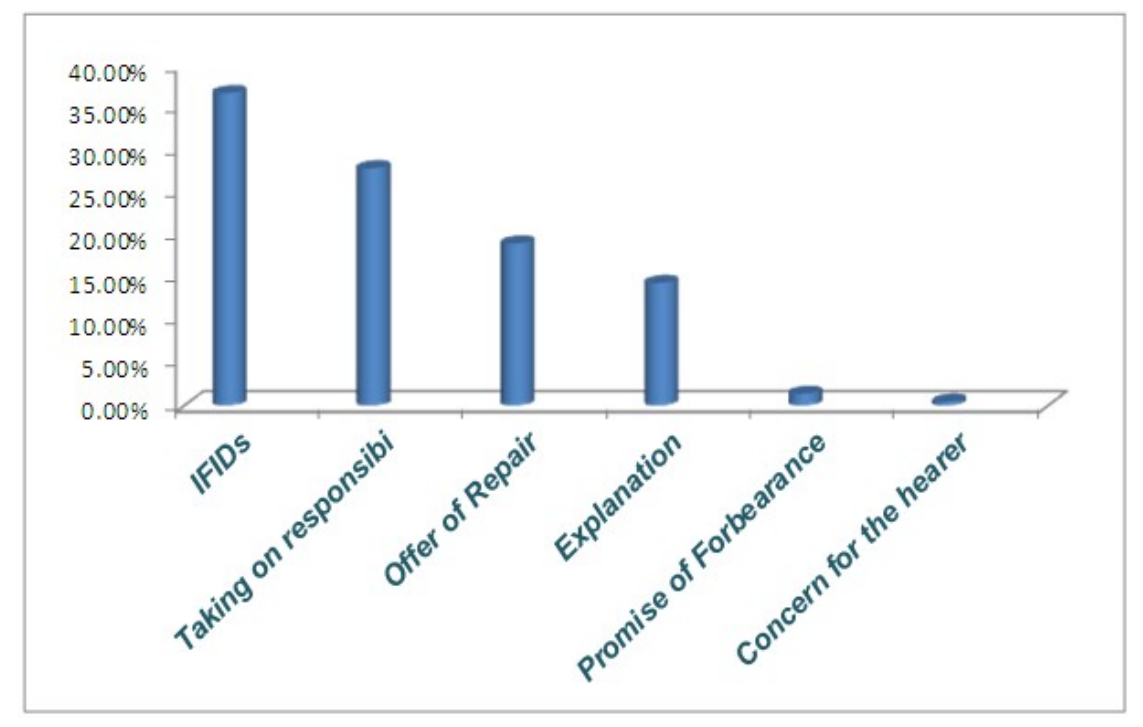

Figure 1. Apology strategies across all the situations 
The above bar graph shows the percentage of the most frequently used strategy to the least frequent one as a whole. As the figure illustrates, among the apology strategies, IFIDs used most by respondents compared to the concern for the hearer which was used the least.

Table 5. Frequency and percentages of request strategies across situations

\begin{tabular}{lllllllll}
\hline \multirow{2}{*}{ Strategies } & \multicolumn{2}{c}{ Situation 1 } & \multicolumn{2}{l}{ Situation 2 } & \multicolumn{2}{l}{ Situation 3 } & \multicolumn{2}{l}{ Total } \\
& $\mathbf{F}$ & $\mathbf{P}$ & $\mathbf{F}$ & $\mathbf{P}$ & $\mathbf{F}$ & $\mathbf{P}$ & & \\
\hline I. Direct Expressions & 16 & $61.4 \%$ & 17 & $58.6 \%$ & 28 & $96.5 \%$ & 62 & $72.6 \%$ \\
1. Imperatives & 15 & $57.6 \%$ & 16 & $55.1 \%$ & 27 & $93.1 \%$ & 58 & $69 \%$ \\
2. Performatives & 1 & $3.8 \%$ & 0 & - & 0 & - & 1 & $1.1 \%$ \\
3. Implicit Performatives & 0 & - & 1 & $3.4 \%$ & 0 & - & 1 & $1.1 \%$ \\
4. Obligation Statements & 0 & - & 0 & - & 1 & $3.4 \%$ & 1 & $1.1 \%$ \\
5. Want Statements & 0 & - & 0 & - & 0 & - & 0 & 0 \\
II. Indirect Expressions & - & - & - & - & - & - & - & $27.3 \%$ \\
II. A. Conventional indirect & 10 & $38.4 \%$ & 12 & $41.3 \%$ & 1 & $3.4 \%$ & 23 & $27.3 \%$ \\
6. Preparatory questions & 8 & $30.7 \%$ & 11 & $37.9 \%$ & 0 & - & 19 & $22.6 \%$ \\
7. Suggestions & 0 & - & 0 & - & 0 & - & 0 & 0 \\
8. Permissions & 1 & $3.8 \%$ & 1 & $3.4 \%$ & 0 & - & 2 & $2.3 \%$ \\
9. Mitigated Preparatory & 1 & $3.8 \%$ & 0 & - & 0 & - & 1 & $1.1 \%$ \\
10. Mitigated Wants & 0 & - & 0 & - & 1 & $3.4 \%$ & 1 & $1.1 \%$ \\
II. B. Non-conventional indirect & 0 & - & 0 & - & 0 & - & - & - \\
11. Strong hint & 0 & - & 0 & - & 0 & - & 0 & 0 \\
12. Mild hint & 0 & - & 0 & - & 0 & - & 0 & 0 \\
Total & 26 & $100 \%$ & 29 & $100 \%$ & 29 & $100 \%$ & 84 & $100 \%$ \\
\hline
\end{tabular}

The table above represents the intermediate respondents' abilities in order to ask for a request in three different situations. Situation 1 was regarding asking another student to turn the music down, situation 2 was to ask the teacher to speak slower and situation 3 was to ask a student to turn the cell phone off in the classroom as a teacher. The situations required the request from three different social standings. Based on the WDCT responses, the respondents' answers were assessed in terms of direct expressions, conventional indirect expressions and non-conventional indirect expressions.

The data show that the learners made use of direct strategies (72.61\%) more than indirect strategies (27.36\%). In other words, they used direct strategies three times more than indirect ones. Regarding the indirect strategies, they used just conventional indirect forms.

Looking at the strategies used holistically, direct and indirect ones, imperatives with $69.04 \%$ stand the first position and has been used as the first most frequently strategy followed by preparatory questions with $22.61 \%$ and permissions with $2.38 \%$ as the second and third most frequent strategies opted out by the learners. Other strategies such as Performatives, Implicit Performatives, Obligation Statements, Mitigated Preparatory, Mitigated Wants had the same frequency with $1.19 \%$ stand the forth position and Want Statements, Suggestions, Strong hint and Mild hint were not opted out by learners at all.

As the social power of the respondents rose in situation 3, more respondents, more than $93 \%$, used imperatives to request while in situations 2 and 3, the results were revealing that the respondents could not distinguish the situations as they almost used the same form or strategy talking to a classmate and a teacher. $57.69 \%$ of the respondents used imperatives in situation 1 and about $55 \%$ in situation 2 . While only 1 respondent had a correct answer by obliging the respondent to turn the cell phone off as a teacher, respondents showed low ability to use performatives. In general, using direct expressions, respondents could use performatives with a higher knowledge of the social situation. Also, none of the respondents opted out the expression using the word "want".

Respondents, however, showed lower ability in producing conventional and non-conventional strategies. For conventional indirect statements, only in situation $1(31 \%)$ and situation $3(38 \%)$ the respondents could ask preparatory questions before they ask their request. The respondents showed zero ability in giving suggestions 
for their request. About 4\% of the respondents, both in situation 1 and 2, asked for permission. This fact is due to equal and lowers imposition rank which was understood by the learners. In case of non-conventional direct requests, the respondents were not able to give any hint either strong or mild in any of the three situations. Therefore, they did not have enough knowledge in this regard.

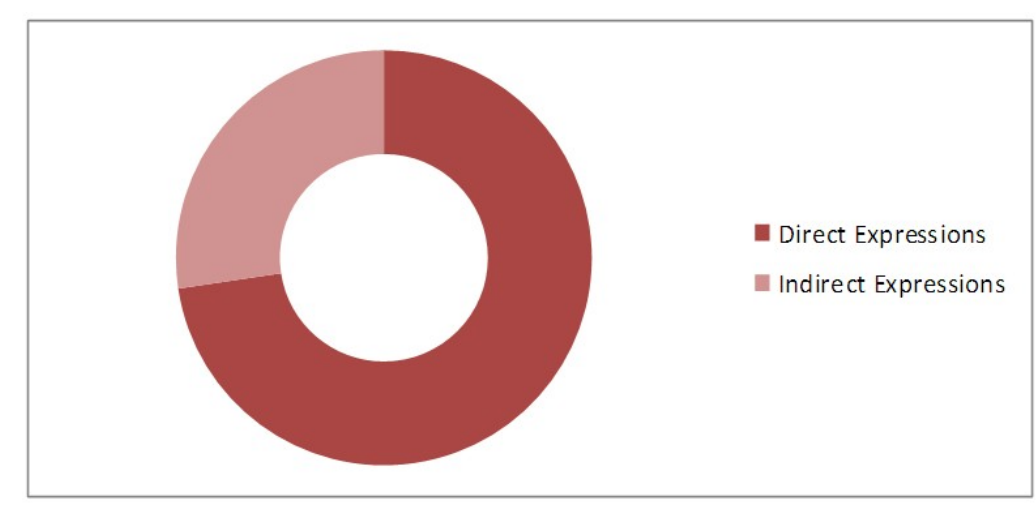

Figure 2. Request strategies across all the situations

The above pie chart shows that the direct strategies with $72.6 \%$ were opted out three times more than indirect ones with $27.3 \%$ in performing the request.



Figure 3. The most frequent used request strategies in all situations

This bar graph shows the most frequent strategies in all of the three situations. As the figure shows, the imperatives strategy is the most used strategy among other strategies followed by preparatory questions and permissions strategies as the second and third most frequently used strategies across all the situations.

Table 6. The frequency and percentages of suggestion strategies across all situations

\begin{tabular}{|c|c|c|c|c|c|c|c|c|c|c|c|c|c|}
\hline \multirow{2}{*}{$\begin{array}{l}\text { Situations } \\
\text { Strategies }\end{array}$} & \multicolumn{2}{|c|}{ One } & \multicolumn{2}{|c|}{ Two } & \multicolumn{2}{|c|}{ Three } & \multicolumn{2}{|c|}{ Four } & \multicolumn{2}{|c|}{ Five } & \multicolumn{2}{|l|}{ Six } & \multirow{2}{*}{ Total } \\
\hline & $\mathrm{F}$ & $\mathrm{P}$ & $\mathrm{F}$ & $\mathrm{P}$ & $\mathrm{F}$ & $\mathrm{P}$ & $\mathrm{F}$ & $\mathrm{P}$ & $\mathrm{F}$ & $\mathrm{P}$ & $\mathrm{F}$ & $\mathrm{P}$ & \\
\hline 1) Let's & 0 & - & 0 & - & 0 & - & 1 & $1.6 \%$ & 1 & $1.4 \%$ & 0 & - & \\
\hline 2) Certain models and & 19 & $48.7 \%$ & 37 & $57.8 \%$ & 37 & $53.6 \%$ & 26 & $41.9 \%$ & 30 & $44.1 \%$ & 15 & $30.6 \%$ & $46.7 \%$ \\
\hline
\end{tabular}




\begin{tabular}{|c|c|c|c|c|c|c|c|c|c|c|c|c|c|}
\hline \multirow{2}{*}{$\begin{array}{l}\text { Situations } \\
\text { Strategies } \\
\text { semi-models }\end{array}$} & \multicolumn{2}{|c|}{ One } & \multicolumn{2}{|c|}{ Two } & \multicolumn{2}{|c|}{ Three } & \multicolumn{2}{|c|}{ Four } & \multicolumn{2}{|c|}{ Five } & \multicolumn{2}{|l|}{ Six } & \multirow{2}{*}{ Total } \\
\hline & $\mathrm{F}$ & $P$ & $\mathrm{~F}$ & $P$ & $\mathrm{~F}$ & $\mathrm{P}$ & $\mathrm{F}$ & $\mathrm{P}$ & $\mathrm{F}$ & $\mathrm{P}$ & $\mathrm{F}$ & $\mathrm{P}$ & \\
\hline 3) Wh-questions & 4 & $10.2 \%$ & 4 & $6.2 \%$ & 10 & $14.4 \%$ & 3 & $4.8 \%$ & 3 & $4.4 \%$ & 3 & $6.1 \%$ & $7.6 \%$ \\
\hline 4) Conditionals & 3 & $7.6 \%$ & 1 & $1.5 \%$ & 5 & $7.2 \%$ & 7 & $11.2 \%$ & 6 & $8.8 \%$ & 7 & $14.2 \%$ & $8.2 \%$ \\
\hline 5) Performatives & 11 & $28.2 \%$ & 13 & $20.3 \%$ & 10 & $14.4 \%$ & 4 & $6.4 \%$ & 8 & $11.7 \%$ & 10 & $20.4 \%$ & $15.9 \%$ \\
\hline $\begin{array}{l}\text { 6) Pseudo cleft } \\
\text { structures }\end{array}$ & 1 & $2.5 \%$ & 4 & $6.2 \%$ & $\mathbf{0}$ & - & $\mathbf{0}$ & - & $\mathbf{0}$ & - & $\mathbf{0}$ & - & $1.4 \%$ \\
\hline $\begin{array}{l}\text { 7) Extraposed } \\
\text { to-clauses }\end{array}$ & $\mathbf{0}$ & - & 2 & $3.1 \%$ & 1 & $1.4 \%$ & $\mathbf{0}$ & - & $\mathbf{0}$ & - & $\mathbf{0}$ & - & $0.8 \%$ \\
\hline 8) Yes/No questions & $\mathbf{0}$ & - & 1 & $1.5 \%$ & 1 & $1.4 \%$ & $\mathbf{0}$ & - & 3 & $4.4 \%$ & $\mathbf{0}$ & - & $1.4 \%$ \\
\hline 9) Imperatives & 1 & $2.5 \%$ & 2 & $3.1 \%$ & 5 & $7.2 \%$ & 21 & $33.8 \%$ & 17 & $25 \%$ & 14 & $28.5 \%$ & $17 . \%$ \\
\hline Total & & & & & & & & & & & & & \\
\hline
\end{tabular}

As the table shows, the respondents produced about 351 suggestion statements in all the six situations. Using certain models and semi modals with percentages ranging between $30.61 \%$ to $57.81 \%$ was the most frequent strategy used by respondents in all situations. Let's strategy, on the other hand, was the least used strategy by the respondents and less than $2 \%$ of the respondents used this strategy in situation 4 and 5 .

In addition, besides modals and semi-modals, the respondents utilized imperative statement (17\%) and performatives $(15.9 \%)$ to make suggestions. These two strategies were the second and third frequently used strategies among other strategies. The respondents also used conditional sentences and wh-questions to perform the speech act of suggestion but they employed these strategies less than other ones. Other low frequent strategies used by the respondents were extraposed to-clauses $(0.8 \%)$, Pseudo Cleft structures and Yes/No questions (1.45).

Therefore, it is inferred that the range and frequency of strategies in all of the situations and also in each situation do not differ significantly to show drastic variations in the use of different strategies by learners. As a result, learners' use of strategies were confined to modals since this strategy comprises about half of the strategies opted out by learners. So, it can be said that they were not aware of different context and contextual factors of social power, distance and imposition to be considered by them in choosing more appropriate pragmalinguistic forms in different situations.

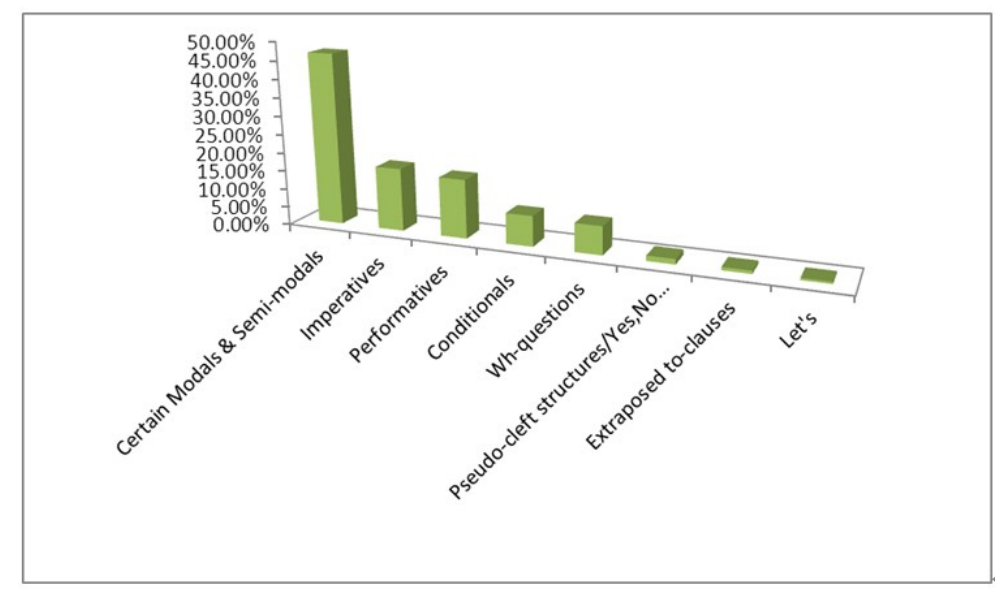

Figure 4. Suggestion strategies across all the situations 
The above figure shows the strategies used in suggestion situations in all six situations from the most utilized one to the least. As it can been seen, certain models and semi-modals, imperatives, performatives, conditional sentences, wh-questions, pseudo-cleft structures and yes,no questions, extraposed to-clauses and let's structure were opted out by learners respectively to suggest different things to the hearer.

\section{Discussion}

As the findings showed, the learners mostly utilized the routinized strategies in performing the speech acts. As a whole, the findings point to the learners' lack of both pragmalinguistics and sociopragmatics competences. This finding could be attributed to the fact that speech acts mirror the routinized language behavior (Dastjerdi \& Farshid, 2011).

Moreover, the results revealed that there were not so much differences in the frequency, shift and type of speech acts strategies or semantic formulas utilized in the production of speech acts by Iranian EFL learners in responding to a higher, an equal, and a lower-status person. In other words, EFL learners did not use different strategies and their use of semantic formulas was almost similar across most of the situations. In fact, they did not consider the contextual or sociopragmatic variables of social power, social distance and imposition across the situations. This finding can be discussed in light of interlanguage pragmatics theory (politeness theory) and SLA theory (Schmidt's Noticing Hypothesis).

The finding of this study is inconsistent with politeness theory since as Brown and Levinson (1987) proposed, the speaker should consider the three contextual factors of distance, power and imposition in performing the face-threatening acts. In fact, there is a direct relationship between language use and these three variables. The findings of this study showed that the learners nearly opted out the identical strategies or semantic formulas in performing the speech acts to a higher, an equal and a lower status person just with minor variations. It means that they did not consider the three situational/contextual variables of social distance, power and imposition.

Moreover, based on Schmidt's noticing hypothesis (1995, p. 30), two levels of noticing and understanding of pragmatic features are identified, noticing and understanding. Noticing refers to the "conscious registration of the occurrence of some event," while understanding implies "the recognition of some general principle, rule, or pattern. Noticing refers to surface level phenomena and item learning, while understanding refers to deeper level (s) of abstraction related to (semantic, syntactic, or communicative) meaning, system learning". In pragmatics domain, awareness that on a particular occasion someone says to his/her interlocutor the statement like "I'm terribly sorry to bother you, but if you have time could you look at this problem?" is something pertinent to noticing. Connecting a variety of forms by considering the politeness issue and recognizing their co-occurrence with the elements of context or contextual factors such as social distance, power, level of imposition and so on are all matters of understanding. Therefore, it can be discussed that the learners may just have reached the noticing level to pick up a semantic formula and produce the speech acts without considering and understanding the contextual variables underlying the choice of appropriate strategy or linguistic form. In other words, they have not reached to the deeper levels of abstraction and rule learning.

The previous section discussed the weak performance of Iranian EFL learners generally. The following section discusses the results of learners' performance with regard to each speech act in relation to those of the past studies conducted in the area. The findings of learners' performance with regard to the speech act of request revealed that learners mostly made use of the direct strategies (72.6\%) compared to the indirect ones $(27.3 \%)$ in making requests in all the situations. Among the direct types, imperative strategy with $69 \%$ is among the most frequently direct used strategy while preparatory question with $22.6 \%$ constitutes the most used strategy among the indirect types. Non-conventional indirect strategies were not used by learners at all. Contrary to such findings, Alfattah (2009) found that Yemeni EFL learners employed the indirect strategies (query-preparatory) as the most frequent request strategies. The findings of Ahanggari and Shoghli's (2011) research, too, showed that both Iranian EFL learners and Canadian native speakers utilized conventionally indirect strategies as manifested by the use of query-preparatory.

The overuse of direct strategies by Iranian EFL learners in this study can be justified based on the fact that learners are not provided with sufficient opportunities to develop and learn a variety of request strategies and semantic formulas. Moreover, it seems that teachers mostly make direct requests to students in their interactions in a classroom context due to the contextual features of the classroom and teacher's status as an authority from whom learners can gain the most reliable source of information. It is also of significance that first form learners encounter and learn in their school textbooks is the direct type of request.

In terms of the speech act of apology, learners were asked to provide answers in three different situations with higher, lower and equal status, high and low social distance and high and low impositions. The results showed 
that $36.7 \%$ of learners opted out the IFID strategy, $27.8 \%$ taking on responsibility, $19 \%$ offer of repair as three most frequent apology strategies. This finding is partially consistent with Istifei's (2009) research who found that the most used strategy by Turkish EFL learners was IFID+ Explanation (e.g. I'm sorry, my daughter was ill. I'm sorry, I had to go to the police station).

In contrast to the finding of this study, a noticeable percentage of Tunisian university students in the study of Jebahi (2011) and Sudanese speakers denied the responsibility for the committed offence and they shifted the responsibility to other sources with the use of accounts or explanations. The use of IFID as the most opted out strategy by Iranian EFL learners in this study can be attributed to some facts. The first point is that IFID (Illocutionary Force Indicating Device) is the most central form of apology in many languages (Al-Zumor, 2011). Therefore, it is logical to presume that the justification of more use of this form compared to other strategies by Iranian EFL learners is based on this fact. Another point is that as Owen (1983) declares, the most conventionalized and routinized strategies for apologizing are IFIDs as the center of speech act category which also represents the verbal routines and syntactic formula. Taking on responsibility and offer of repair as the second and third most frequently used apology strategies showed that Iranian EFL learners paid attention to their hearer's positive face by threatening their own positive face. This matter can be justified by this fact that the concept of face is of significant value in Iranian culture. Therefore, learners tried to save the hearer's face.

Regarding the speech act of suggestion, modals and semi-modals with the percentage of $46.7 \%$ and imperatives with $17 \%$ were among the most opted out strategies among others by learners. Consistent with this is $\mathrm{Gu}(2014)$ who found out that Chinese learners made use of more modal verbs, explicit performatives and conditional forms in making suggestions. Contrary to such findings, Liu and Zhao (2007) showed that all the instructors (native speaking and non-native speaking instructors) utilized more direct suggestions such as performative verbs and noun of suggestion even though the non-native speaking instructors provided more direct strategies than native speaking instructors. On the other hand, the least used strategy was let's structure. This finding is in sharp contrast with that of Gahrouei (2013) who showed that "let's" is the most frequently used structure for making suggestions among TEFL students.

It can be discussed that as Kasper (1996, as cited in Jiang, 2006) declares, learners' lack of appropriate pragmatic competence in possessing a full range of linguistics forms can be attributable to the pedagogical materials which do not provide enough input. Moreover, Scotton and Bernsten (1988) claimed that there is no consistency between textbook language or samples and real-life language. Since Top-Notch series is the dominant textbooks taught in most institutes and the institutes observed by the researcher, they present suggestion samples in patterns such as modals, imperatives and interrogatives whereas no sample of let's syntactic structure is seen in these books. Therefore, more use of modals and imperatives and less use of let's structure by Iranian EFL learners can be justified on this basis.

As a whole, the results showed that the learners mostly utilized more reutilized strategies to perform the speech acts and the frequency and type of the strategy used is not different significantly across different situations with regard to the contextual factors. It means that the contextual factors of social power, distance and imposition did not affect the learners' choice of the strategies that much. It can be concluded that the learners did not aware of the mentioned factors since they almost made use of the same strategies across different situations. This study has a number of limitations. The first limitation is that Iranian EFL learners' interlanguage pragmatic knowledge was tapped by means of WDCT due to its practicality for a large sample. So, the findings can be limited to the learners' production of some specific speech acts. The second limitation is the selection of EFL learners. The participants were from one province in Iran. So, they may not represent all Iranian EFL learners. The last limitation is the fact that although all participants were considered intermediate learners, they were not homogeneous in age and educational background which may have influenced the results of the current study.

Based on the results of this study, it is suggested that although learners' interlanguage pragmatic knowledge was measured through WDCT, future research could employ other data collection instruments such as role-plays or other tasks to examine multiple turns of interaction. In this study, the data analysis was based on answers to a written DCT questionnaire. The DCT format is constructed for eliciting pair responses, so multiple turns of interaction cannot be examined. Moreover, the contextual variables examined in this study were "power," "social distance," and "imposition of the task" .Further studies could be designed to examine other contextual factors, such as age and gender of interlocutors in situations.

\section{References}

Al-Fattah, M. (2009). Apology strategies of Yemeni EFL university students. MJAL, 2(3), 223-249.

Al-Zubeiry, H. Y. (2013). Intercultural miscommunication in the production of communicative patterns by Arab 
EFL learners. International Journal of English Linguistics, 3(5), 69-77. http://dx.doi.org/10.5539/ijel. v3n5p69

Al-Zumor, A. W. Q. G. (2011). Apologies in Arabic and English: An interlanguage and cross-cultural study. Journal of King Saud University Languages and Translation, 23(1), 19-28. http://dx.doi.org/10.1016/j. jksult.2010.02.001

Bardovi-Harlig, K., \& Dornyei, Z. (1998). Do language learners recognize pragmatic violations? Pragmatic versus grammatical awareness in instructed L2 learning. TESOL Quarterly, 32(2), 233-262. http://dx.doi. org/10.2307/3587583

Blum-Kulka, S. (1989). Playing it safe: The role of conventionality in indirectness. In S. Blum-Kulka, J. House-Edmondson, \& G. Kasper (Eds.), Cross-cultural pragmatics: Requests and apologies (pp. 37-70). Norwood, NJ: Ablex.

Blum-Kulka, S., House, J., \& Kasper, G. (1989). Cross-cultural pragmatics: Requests and apologies. New Jersey: Ablex.

Brown, P., \& Levinson, S. C. (1987). Politeness: Some universals in language usage. Cambridge: Cambridge University Press.

Eslami-Rasekh, Z. (2011). In their own voices: Reflections of native and nonnative English speaking TESOL graduate students on on-line pragmatic instruction to EFL learners. Electronic Journal for Teaching English as a Second or Foreign Language, 15(2), 1-21.

Farahian, M., Rezaee, M., \& Gholami, A. (2012). Does direct instruction develop pragmatic competence? Teaching refusals to EFL learners of English. Journal of Language Teaching and Research, 3(4), 814-821. http://dx.doi.org/10.4304/jltr.3.4.814-821

Gahrouei, V. (2013). A sociolinguistic study of speech act of suggestion in persian EFL learners. The Iranian EFL Journal, 9(1), 241-249.

$\mathrm{Gu}, \mathrm{T}$. (2014). A corpus-based study on the performance of the suggestion speech act by Chinese EFL learners. International Journal of English Linguistics, 4(1), 103-111. http://dx.doi.org/10.5539/ijel.v4n1p103

Hamouda, A. (2014). The effect of explicit instruction on developing Saudi EFL learners' pragmatic competence in refusal formulas. Research Journal of English Language and Literature, 2(1), 138-160.

Jebahi, Kh. (2011). Tunisian university students' choice of apology strategies in a discourse completion task. Journal of Pragmatics, 43, 648-662. http://dx.doi.org/10.1016/j.pragma.2010.09.008

Jiang, X. (2006). Suggestions: What should ESL students know? System, 34, 36-54. http://dx.doi.org/10.1016/j. system.2005.02.003

Kasper, G. (2000). Data collection in pragmatics research. In H. Spencer-Oatey (Ed.), Culturally speaking (pp. 316-341). London: Continuum.

Kasper, G. (2006). Speech acts in interaction: Towards discursive pragmatics. In K. Bardovi-Harlig, C. Félix-Brasdefer, \& A. S. Omar (Eds.), Pragmatics and language learning (pp. 281-314). Honolulu, HI: National Foreign Language Resource Center, University of Hawai'I at Manoa.

Liu, J. (2005). Developing a pragmatics test for Chinese EFL learners. Language Testing, 24(3), 391-415.

Liu, Y., \& Zhao, J. (2007). Suggestions in teacher-student conferences. Arizona Working Papers in SLA and Teaching, 14, 59-74.

Marlina, R. (2013). Globalization, internationalization, and language education: An academic program for global citizens. Multilingual Educations, 3(3), 1-21.

Martínez-Flor, A. (2006). Task effects on EFL learners' production of suggestions: A focus on elicited phone messages and Emails. Journal of English and American Studies, 33, 47-64.

Martinez-Flor, A., \& Uso-Juan, E. (2010). Pragmatics and speech act performance. In A. Martinez-Flor, \& E. Uso-Juan (Eds.), Speech Act Performance: Theoretical, Empirical and Methodological (Issues 3-20). Amesterdam: John Benjamins. http://dx.doi.org/10.1075/11lt.26

Nguyen, M. T. T. (2011). Learning to communicate in a globalized world: To what extent do school textbooks facilitate the development of intercultural pragmatic competence? RELC Journal, 42(1), 17-30. http://dx.doi. org/10.1177/0033688210390265 
Olshtain, E., \& Cohen, A. D. (1983). Apology: A speech-act set. In N. Wolfson, \& E. Judd (Eds.), Sociolinguistics and language acquisition (pp. 18-36). Cambridge: Newbury House.

Pishghadam, R., \& Sharafadini, M. (2011). A contrastive study into the realization of suggestion speech act: Persian vs. English. Canadian Social Science, 7(4), 230-239.

Rafieyan, V., Sharafi-Nejad, M., \& Siew-Eng, L. (2014). Effect of pragmatic instruction on sustainable development of pragmatic awareness. Journal of Studies in Education, 4(1), 206-218. http://dx.doi.org/10. 5296/jse.v4i1.5088

Rashidi, N., \& Ramezani, S. (2013). On the impact of the role-play technique on the development of FL learners' pragmatic competence before and after formal instruction. International Symposium on Challenges (ISLC), 183-196.

Schmidt, R. (1995). Consciousness and foreign language learning: A tutorial on the role of attention and awareness in learning. In R. Schmidt (Ed.), Attention and Awareness in Foreign Language Learning (pp. 1-63). Honolulu, HI: University of Hawaii, Second Language \& Curriculum Center.

Scotton, C. M., \& Bernsten, J. (1988). Natural conversations as a model for textbook dialogue. Applied Linguistics, 9(4), 372-384. http://dx.doi.org/10.1093/applin/9.4.372

Simin, S., Eslami-Rasekh, Z., Eslami-Rasekh, A., \& Ketabi, S. (2014). The effect of explicit teaching of apologies on Persian EFL learners' performance: When e-communication helps. International Journal of research Studies in Language Learning, 3(4), 71-84. http://dx.doi.org/10.5861/ijrsll.2014.661

Taguchi, N. (2008). Cognition, language contact, and the development of pragmatic comprehension in a study abroad context. Language Learning, 58(1), 33-71. http://dx.doi.org/10.1111/j.1467-9922.2007.00434.x

\section{Copyrights}

Copyright for this article is retained by the author(s), with first publication rights granted to the journal.

This is an open-access article distributed under the terms and conditions of the Creative Commons Attribution license (http://creativecommons.org/licenses/by/3.0/). 